\title{
Molecular identification, L-lactic acid production, and antibacterial activity of Bacillus strains isolated from soils
}

\author{
Vasana Tolieng ${ }^{1}$, Auttaporn Booncharoen ${ }^{2}$, Ratthanatda Nuhwa ${ }^{2}$, Nuttha Thongchul ${ }^{1}$, Somboon Tanasupawat ${ }^{* *}$ \\ ${ }^{1}$ Institute of Biotechnology and Genetic Engineering, Chulalongkorn University, Bangkok, Thailand. \\ ${ }^{2}$ Department of Biochemistry and Microbiology, Faculty of Pharmaceutical Sciences, Chulalongkorn University, Bangkok, Thailand.
}

\begin{tabular}{|c|c|}
\hline ARTICLE INFO & ABSTRACT \\
\hline $\begin{array}{l}\text { Received on: } 20 / 08 / 2018 \\
\text { Accepted on: } 12 / 09 / 2018 \\
\text { Available online: } 31 / 10 / 2018\end{array}$ & $\begin{array}{l}\text { Fourteen spore-forming bacteria isolated from soils were evaluated for their taxonomic characterization, lactic acid } \\
\text { production, and antimicrobial activity. They were belonged to the genus Bacillus and were closely related to Bacillus } \\
\text { coagulans LMG } 6326^{\mathrm{T}} \text { with } 97.48 \%-98.48 \% \text { similarity, based on } 16 \mathrm{~S} \text { rRNA gene analyses. Repetitive genomic } \\
\text { element-PCR (REP-PCR) fingerprinting using the primers sets; BOX-PCR, ERIC-PCR, GTG } \text {-PCR, and REP- }^{-P} \text {, }\end{array}$ \\
\hline $\begin{array}{l}\text { Key words: } \\
\text { Antibacterial activity, } \\
\text { Bacillus, lactic acid, Rep- } \\
\text { PCR, soil. }\end{array}$ & $\begin{array}{l}\text { PCR were used to differentiate among the species. Clustering of the isolates with the PCR fingerprint dendrograms } \\
\text { obtained two groups. Group } 1 \text { consists of two isolates, JC- } 3 \text { and JC- } 11(14.29 \%) \text {, and the rest of isolates }(85.71 \%) \\
\text { were distributed in another group. Based on } 16 \mathrm{~S} \text { rRNA sequence analysis and REP-PCR and the phenotypic } \\
\text { characteristics, they were classified as a novel Bacillus species. These isolates were screened for lactic acid production } \\
\text { and antimicrobial efficiency, and the results revealed that they produced L-lactic acid in the range of } 1.7 \pm 0.1 \mathrm{~g} / 1-32.6 \\
\pm 0.7 \mathrm{~g} / 1 \text { at } 98.58 \% \pm 0.06 \%-100.00 \% \pm 0.00 \% \text { optical purity. Among them, only JC- } 19 \text { was found to show inhibitory } \\
\text { activity against Kocuria rhizophila ATCC } 9341 \text {. }\end{array}$ \\
\hline
\end{tabular}

\section{INTRODUCTION}

Bacillus species are the largest members of the Family Bacillaceae in Phylum Firmicutes. They are Gram-positive aerobic or facultative anaerobic endospore-forming rods. More than 200 Bacillus species are widely distributed in nature but are predominant in soils with diverse phenotypic and phylogenetic characteristics (Vos et al., 2011). Bacillus strains have a great potential to use in various applications as enzymes producers, probiotics, bioprotection products, vitamins, and antibiotics, meanwhile, some strains cause food poisoning and serious infection. They play critical roles in the biodegradation of pollutants in the environment (Feto, 2016). A spore-forming lactic acid bacteria, Bacillus coagulans that shares characteristics of both genera Lactobacillus and Bacillus are marketed probiotics (earlier known as Lactobacillus sporogenes) which widely used as a microbial supplement for improving

\footnotetext{
${ }^{*}$ Corresponding Author

Somboon Tanasupawat, Department of Biochemistry and Microbiology, Faculty of Pharmaceutical Sciences, Chulalongkorn University, Bangkok, Thailand.E-mail: somboon.T@ chula.ac.th
}

digestive health and nutrient utilization (Liao and Nyachoti, 2017). They also used as an alternative to antibiotics in animal feed and have a beneficial role in improving products quality in farming industries, especially in pig and poultry production (Ezema, 2013). From their numerous characteristics, it was hard to distinguish within the species (De Clerck et al., 2004). To overcome the conventional identification based on morphological, physiological and biochemical characteristics, several molecular techniques have been developed using polymerase chain reaction (PCR) consisting to amplification of $16 \mathrm{~S}$ ribosomal DNA sequences with broad-range primers for rapid identification (Jensen et al., 1993). This PCR technique provided a rapid and accurate description of species, which has led to large changes in bacterial taxonomy. Several PCR techniques (RT-PCR and Rep-PCR) were developed for detection and species differentiation of Bacillus group (Da Silva and Valicente, 2013; Oliwa-Stasiak et al., 2011). Repetitive sequence-based PCR (Rep-PCR) method is useful to differentiate microbes by using specific primers which have been designed to match the conserved repetitive sequences distributed in bacterial genomes. The amplification product of DNA fragments consisting of sequences between the repetitive elements at different sizes 
can be fractionated by electrophoresis, and the resulting DNA fingerprint patterns can be compared to analyze the genetic relationship between strains. Identification of Bacillus group using Rep-PCR showed high specific results at low cost (Rampadarath et al., 2015).

The present study was undertaken to isolate, identify, and to compare strains of Bacillus isolated from soil by using a combination of morphological, physiological, biochemical characteristics and 16S rRNA sequence analysis. The genetic similarity of strains was characterized using BOX-PCR, ERIC-

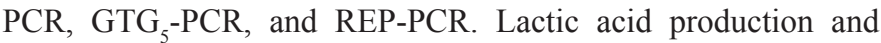
antimicrobial ability were also investigated.

\section{MATERIALS AND METHODS}

\section{Sources and isolation methods}

A total of 14 bacterial strains were isolated from soil samples collected from Nakornnayok Province and Bangkok, Thailand (Table 1) by enrichment approach using Glucose-Yeast extract-Peptone (GYP) broth which composed of (per liter) $10 \mathrm{~g}$ glucose, $5 \mathrm{~g}$ yeast extract, $5 \mathrm{~g}$ peptone, $250 \mathrm{mg} \mathrm{KH}_{2} \mathrm{PO}_{4}, 250 \mathrm{mg}$ $\mathrm{K}_{2} \mathrm{HPO}_{4}$, and $10 \mathrm{ml}$ salt solution $\left(400 \mathrm{mg} \mathrm{MgSO} \cdot 7 \mathrm{H}_{2} \mathrm{O}, 20 \mathrm{mg}\right.$ $\mathrm{MnSO}_{4} \cdot 5 \mathrm{H}_{2} \mathrm{O}, 20 \mathrm{mg} \mathrm{FeSO} \cdot 7 \mathrm{H}_{2} \mathrm{O}$, and $20 \mathrm{mg} \mathrm{NaCl}$ per $100 \mathrm{ml}$ solution) for 3 days at $37^{\circ} \mathrm{C}$ under anaerobic conditions (Prasirtsak et al., 2013). The aliquot was streaked on GYP agar plate containing $0.5 \% \mathrm{CaCO}_{3}$ and the single colony was picked up and purified on GYP agar plates for further study.

\section{Identification methods}

\section{Phenotypic characterization}

The isolates were identified based on their phenotypic characteristics, including morphological characteristic on GYP agar plate containing $\mathrm{CaCO}_{3}$ after incubated under anaerobic conditions at $37^{\circ} \mathrm{C}$ for 2 days. Gram staining, spore formation, catalase activity, nitrate reduction, arginine, starch and gelatin hydrolysis were determined (Cowan and Steel, 2004; Tanasupawat et al., 1998). The effects of $\mathrm{NaCl}$ tolerance in GYP broth supplemented with $0 \%, 3 \%$, $5 \%, 7 \%, 9 \%$, and $10 \%(\mathrm{w} / \mathrm{v}) \mathrm{NaCl}$, temperature for growth at $15^{\circ} \mathrm{C}$, $20^{\circ} \mathrm{C}, 30^{\circ} \mathrm{C}, 37^{\circ} \mathrm{C}, 45^{\circ} \mathrm{C}, 50^{\circ} \mathrm{C}, 55^{\circ} \mathrm{C}, 60^{\circ} \mathrm{C}, 65^{\circ} \mathrm{C}$ and $\mathrm{pH}$ growth at $\mathrm{pH} 4.5-9.0$ (0.5 interval) were performed. Acid from carbohydrates was tested as previously described (Tanasupawat et al., 1998).

\section{Genotypic characterization}

Genomic DNA extractions of the isolates were extracted using the AccuPrep ${ }^{\mathrm{TM}}$ Genomic DNA Extraction Kit (Bioneer, Daejeon, Republic of Korea) and the quality and quantity of DNA were measured to determine acceptable purity using Nanodrop ND-2000 UV-Vis spectrophotometer (Thermo Scientific, Wilmington, DE). Repetitive sequence based on polymerase chain reaction (REP-PCR) fingerprinting with BOX-PCR, ERIC-PCR, $\mathrm{GTG}_{5}-\mathrm{PCR}$, and REP-PCR was conducted to obtain the genomic fingerprinting of all bacterial isolates. The oligonucleotide primers used in this study were: for BOX-PCR, BOX-A1R: 5'-CTACGGCAAGGCGACGCTGACG-3', for ERIC-PCR, ERIC-1R: 5'-ATGTAAGCTCCTGGGGATTCAC-3' and ERIC2: 5'-AAGTAAGTGACTGGGGTGAGCG-3', for GTG5-PCR: 5'-GTGGTGGTGGTGGTG-3', and REP-PCR: REP1R-I, 5'-IIIICGICGICATCIGGC-3'. Optimal PCR program for each of the primer sets used was described by Versalovic et al. (1994). Amplification was done in $25 \mu \mathrm{l}$ reaction mixture consisting 100 $\mathrm{ng} / \mu \mathrm{l}$ of template DNA, $10 \times$ PCR reaction buffer containing 20 $\mathrm{mM} \mathrm{MgCl}, 20 \mathrm{pmol} / \mu \mathrm{l}$ each of the primers, $2.5 \mathrm{mM}$ of the dNTPs mixture, and $2 \mathrm{U} / \mu \mathrm{l}$ of Takara Taq DNA polymerase (Takara Bio Inc, Japan). PCR amplification was performed in a Bio-Rad T100 PCR thermal cycler (Bio-Rad Laboratories, Hercules, CA). The BOX-PCR consisted of an initial denaturation step at $97^{\circ} \mathrm{C}$ for 7 minutes, which was followed by 30 cycles of $94^{\circ} \mathrm{C}$ for 1 minute, $53^{\circ} \mathrm{C}$ for 1 minute, $56^{\circ} \mathrm{C}$ for 4 minutes, and final extension at $65^{\circ} \mathrm{C}$ for 16 minutes. For ERIC-PCR and $\mathrm{GTG}_{5}-\mathrm{PCR}$, the conditions were $95^{\circ} \mathrm{C}$ for 5 minutes, which was followed by 30 cycles of $94^{\circ} \mathrm{C}$ for 0.45 minute, $40^{\circ} \mathrm{C}$ for 1 minute, $65^{\circ} \mathrm{C}$ for 10 minutes, and final extension at $65^{\circ} \mathrm{C}$ for 20 minutes. The amplification of REP-PCR was performed as follows: $95^{\circ} \mathrm{C}$ for 5 minutes, which was followed by 45 cycles of $94^{\circ} \mathrm{C}$ for 0.45 minute, $40^{\circ} \mathrm{C}$ for 1 minute, $65^{\circ} \mathrm{C}$ for 10 minutes, and final extension for 20 minutes at $65^{\circ} \mathrm{C}$. The PCR amplification products $(10 \mu \mathrm{l})$ were subsequently visualized by electrophoresis in a $1 \%(\mathrm{w} / \mathrm{v})$ agarose gels $(15 \times$

Table 1. Location of soil samples, isolate number, $16 \mathrm{~S}$ rRNA gene sequence similarity

$(\%)$, and nearest relative.

\begin{tabular}{lccc}
\hline Province & Isolate no. & Similarity (\%) & Nearest relative \\
\hline Nakornnayok & PP-13 & 98.08 & B. coagulans LMG $6326^{\mathrm{T}}$ \\
Nakornnayok & PP-18 & 98.19 & B. coagulans LMG $6326^{\mathrm{T}}$ \\
Bangkok & JC-1 & 97.62 & B. coagulans LMG $6326^{\mathrm{T}}$ \\
Bangkok & JC-3 & 98.07 & B. coagulans LMG $6326^{\mathrm{T}}$ \\
Bangkok & JC-4 & 98.21 & B. coagulans LMG $6326^{\mathrm{T}}$ \\
Bangkok & JC-5 & 98.18 & B. coagulans LMG $6326^{\mathrm{T}}$ \\
Bangkok & JC-6 & 98.17 & B. coagulans LMG $6326^{\mathrm{T}}$ \\
Bangkok & JC-7 & 97.64 & B. coagulans LMG $6326^{\mathrm{T}}$ \\
Bangkok & JC-8 & 97.48 & B. coagulans LMG $6326^{\mathrm{T}}$ \\
Bangkok & JC-11 & 98.08 & B. coagulans LMG $6326^{\mathrm{T}}$ \\
Bangkok & JC-12 & 97.60 & B. coagulans LMG $6326^{\mathrm{T}}$ \\
Bangkok & JC-17 & 97.71 & B. coagulans LMG $6326^{\mathrm{T}}$ \\
Bangkok & JC-19 & 98.21 & B. coagulans LMG $6326^{\mathrm{T}}$ \\
Bangkok & JC-20 & 98.48 & B. coagulans LMG $6326^{\mathrm{T}}$ \\
\hline
\end{tabular}


$25 \mathrm{~cm}$ ) for 2.20 hours at a constant voltage of 150 volts in $0.5 \times$ Tris-borate-Ethylenediaminetetraacetic acid (EDTA) buffer at room temperature $\left(25^{\circ} \mathrm{C}\right)$. The gel was stained with ethidium bromide ( $\mathrm{EtBr} 0.5 \mu \mathrm{g} / \mathrm{ml})$, then the digital image capturing was visualized under UV light using Gel document ${ }^{\mathrm{TM}} \mathrm{XR}^{+}$imaging system (Bio-Rad, USA) and the image was printed. The DNA fingerprint patterns were analyzed by using the software package, GelCompar II version 5.10 (Applied Maths, Kortrijk, Belgium). The similarity among digitized pattern was calculated using Pearson correlation coefficient, and the unweighted pair-group method with average linkages (UPGMA) dendrogram was derived from the profiles. A clustering level of $80 \%$ was regarded as significant grouping (Gevers et al., 2001). The different dendrograms were visually interpreted to set the delineation level separately for each species. For the identification of strains, the 16S rRNA gene was determined as described below.

The gene encoding 16S rRNA was amplified by PCR with the $16 \mathrm{~S}$ bacteria specific $27 \mathrm{~F}$ (5'-AGAGTTTGATCMTGGCTCAG-3') forward and $518 \mathrm{~F}$ (5'-CCAGCAGCCGCGGTAATACG-3') reverse primer. Agarose gel electrophoresis was performed to validate the quality of the PCR product. Purified PCR fragments were sequenced with the both primers and more six primers $\quad 27 \mathrm{~F} \quad\left(5^{\prime}\right.$-AGAGTTTGATCMTGGCTCAG-3'),785F (5'-GGATTAGATACCCTGGTA-3'), 518F (5'-CCAGC AGCCGCGGTAATACG-3'), 800R (5'-TACCAGGGTATCTAATCC-3'), 907R (5'-CCGTCAATTCMTTTRAGTTT-3'), and 1492R (5'-TACGGYTACCTTGTTACGACTT-3'). The amplified 16S rRNA gene sequence was analyzed by Macrogen ${ }^{\circledR}$, Korea. In the phylogenetic analysis, a homology search was carried out using the Basic Local Alignment Search Tool of Nucleotide (BLASTN) search program at the NCBI Website. Sequence gaps and ambiguous nucleotides were removed prior to the construction of phylogenetic trees. Phylogenetic analysis was carried out using neighbor-joining methods (Saitou and Nei, 1987) and was constructed by using the program MEGA7 (Tamura et al., 2013). The confidence value of individual branches was determined with bootstrap values based on 1,000 replications (Felsenstein, 1985). The values for sequence similarity among the closest strains were determined using the EzTaxon server (Kim et al., 2012).

\section{Determination of lactic acid and end product}

Quantification of lactic acids produced by the isolates was performed. All isolates were transferred to GYP agar slant and incubated at $37^{\circ} \mathrm{C}$ for 48 hours under aerobic condition. Cell grew on the slant was inoculated into $50 \mathrm{ml}$ of seed medium consisting of (per liter $10 \mathrm{~g}$ glucose, $15 \mathrm{~g}$ yeast extract, $4 \mathrm{~g} \mathrm{NH}_{4} \mathrm{Cl}$, $0.50 \mathrm{~g} \mathrm{KH}_{2} \mathrm{PO}_{4}, 0.50 \mathrm{~g} \mathrm{~K}_{2} \mathrm{HPO}_{4}, 5 \mathrm{~g} \mathrm{CaCO}_{3}$, and $20 \mathrm{ml}$ salts solution) and incubated at $37^{\circ} \mathrm{C}, 200 \mathrm{rpm}$ for 5 hours. Each 25 $\mathrm{ml}$ pre-culture broth was transferred into $25 \mathrm{ml}$ glucose solution (240 g/l) containing $4 \mathrm{~g} \mathrm{CaCO}_{3}$. They were incubated at $37^{\circ} \mathrm{C}$. Samples were collected at 72 hours after that the supernatant was acidified, centrifuged, and diluted to the proper concentration to analyze lactic acid and residual glucose by high-performance liquid chromatography (HPLC) equipped with Biorad, Aminex HPX-87H ion exclusion organic acid column $(300 \mathrm{~mm} \times 7.8$ $\mathrm{mm}$ ) maintained at $45^{\circ} \mathrm{C}$ in a column oven (Shimadzu-CTO6A). An eluent, $0.005 \mathrm{M} \mathrm{H}_{2} \mathrm{SO}_{4}$, was pumped through the system at the flow rate of $0.6 \mathrm{ml} /$ minute (Shimadzu-LC-10 Avp). A refractive index detector (Shimadzu-RID-10A) was used

Table 2. Differential phenotypic characteristics of the isolates.

\begin{tabular}{|c|c|c|c|c|c|c|c|c|c|c|c|c|c|c|c|c|}
\hline \multirow[b]{2}{*}{ Characteristics } & \multicolumn{16}{|c|}{ Isolate no. } \\
\hline & PP-13 & PP-18 & JC-1 & JC-3 & JC-4 & JC-5 & JC-6 & JC-7 & JC-8 & JC-11 & JC-12 & JC-17 & JC-19 & JC-20 & $\begin{array}{l}\text { LMG } \\
6^{3} 26^{T}\end{array}$ & $\begin{array}{l}\text { KCTC } \\
13078^{\mathrm{T}} \\
\end{array}$ \\
\hline Growth temp $\left({ }^{\circ} \mathrm{C}\right)$ & $30-55$ & $30-55$ & $30-55$ & $30-55$ & $30-60$ & $30-55$ & $30-55$ & $30-55$ & $30-60$ & $30-55$ & $30-60$ & $30-60$ & $30-60$ & $30-55$ & $25-60$ & $20-55$ \\
\hline Max. $\mathrm{NaCl}(\%)$ & 0 & 0 & 0 & 0 & 0 & 0 & 0 & 0 & 3 & 0 & 0 & 3 & 0 & 0 & 3 & 3 \\
\hline MR & - & + & - & - & - & - & - & - & - & + & - & - & - & - & - & - \\
\hline VP & + & + & + & - & - & + & + & + & + & + & - & - & + & - & + & + \\
\hline Aesculin & - & + & - & - & - & - & - & - & + & - & - & + & - & + & - & - \\
\hline \multicolumn{17}{|l|}{ Acid from } \\
\hline L-Arabinose & + & + & - & - & + & + & + & + & - & - & + & + & + & + & - & + \\
\hline D- Cellobiose & + & + & + & - & + & + & + & + & + & + & + & + & + & + & + & - \\
\hline Lactose & + & + & + & + & + & + & - & - & - & + & + & + & + & $\mathrm{w}$ & + & - \\
\hline D-Mannitol & + & + & - & + & - & + & + & + & + & + & + & + & + & - & + & + \\
\hline D-Mannose & + & + & + & + & + & + & + & + & + & + & + & + & + & + & - & + \\
\hline D-Melibiose & + & + & - & + & + & + & - & + & - & + & + & - & + & + & + & - \\
\hline $\begin{array}{l}\text { Methyl- } \alpha \text {-D- } \\
\text { glucoside }\end{array}$ & + & - & - & - & - & + & + & + & - & - & + & + & + & + & $\mathrm{w}$ & + \\
\hline Raffinose & + & + & $\mathrm{w}$ & $\mathrm{w}$ & + & + & + & + & - & $\mathrm{w}$ & + & $\mathrm{w}$ & + & + & w & - \\
\hline Rhamnose & + & + & - & - & - & + & + & + & - & - & + & $\mathrm{w}$ & + & - & - & + \\
\hline D-Ribose & - & - & + & + & + & + & + & $\mathrm{w}$ & + & + & $\mathrm{w}$ & $\mathrm{w}$ & + & $\mathrm{w}$ & - & + \\
\hline Sucrose & + & + & + & - & + & + & + & + & + & + & + & + & + & + & + & - \\
\hline D-Trehalose & + & + & + & + & + & + & + & + & + & + & + & $\mathrm{w}$ & + & + & + & - \\
\hline D-Xylose & + & - & - & - & + & + & + & + & $\mathrm{w}$ & + & + & $\mathrm{w}$ & $\mathrm{w}$ & $\mathrm{w}$ & - & + \\
\hline
\end{tabular}

$+=$ positive reaction; $\mathrm{w}=$ weak reaction; $-=$ negative reaction. 
to detect the organic compounds detail. Lactic concentration and their isomers were analyzed by high-performance liquid chromatography (Prasirtsak et al., 2013).

\section{Screening of antimicrobial activity}

All bacterial isolates were investigated to evaluate their antibacterial activity against tested microorganisms, including three strains of Gram-positive bacteria, Bacillus subtilis ATCC 6633, Kocuria rhizophila ATCC 9341, and Staphylococcus aureus ATCC 6538, two strains of Gram-negative bacteria, Pseudomonas aeruginosa ATCC 27853 and Escherichia coli ATCC 25922, and one of yeast strain, Candida albicans ATCC 10231 by using agar diffusion method (Acar and Goldstein, 1991). The tested bacteria were cultivated on nutrient agar plate (NA, Difco) at $37^{\circ} \mathrm{C}$ and yeast on Sabouraud Dextrose Agar plate (SDA, Difco) at $30^{\circ} \mathrm{C}$, for 24 hours. A new agar plate surface was inoculated by spreading each microorganism and $50 \mu \mathrm{l}$ of culture broth of each isolate was introduced into a $6 \mathrm{~mm}$ diameter hole. The plates were incubated at the same condition. The inhibition zones $(\mathrm{mm})$ were observed and measured.

\section{RESULTS AND DISCUSSION}

\section{Isolation and phenotypic characterization}

Fourteen strains of bacteria consisted of JC-1, JC-3, JC4, JC-5, JC-6, JC-7, JC-8, JC-11, JC-12, JC-17, JC-19, and JC-20 were isolated from the soil in Bangkok, except PP-13 and PP-18 that were isolated from soils in Nakornnayok province (Table 1). Colonies of isolates were circular, smooth, shiny, and white and approximately $1 \mathrm{~mm}$ in diameter after incubation on GYP agar plate at $37^{\circ} \mathrm{C}$ for 2 days. All isolates were catalase positive, oxidase negative, and facultative anaerobe. Methyl red, Voges-Proskauer, and aesculin reactions were variable among each isolate. They grew at $30-55$ to $60^{\circ} \mathrm{C}$, at $\mathrm{pH} 5-8$ and some could grow at $3 \% \mathrm{NaCl}$. Acid was produced from D-fructose, D-galactose, D-glucose, D-maltose, and some isolates produced acid from L-arabinose, D-cellobiose, lactose, dextran, inulin, D-mannitol, D-mannose, D-melibiose, methyl- $\alpha$-D-glucoside, raffinose, rhamnose, D-ribose, sucrose, D-trehalose, and D-xylose as shown in Table 2.

\section{Genotypic characterization}

A total of 14 strains and two type strains, B. coagulans LMG $6326^{\mathrm{T}}$ and B. acidiproducens KCTC $13078^{\mathrm{T}}$ were subjected to PCR fingerprinting. The results of numerical analysis of the generated PCR banding patterns are shown in a dendrogram (Figs. 1-4). The

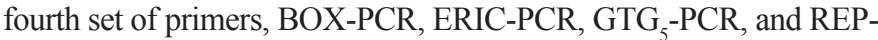
PCR, gave successful amplification with band size lying between 500-5,000 bp, 50-10,000 bp, 200-15,000 bp, and 100-8,000 bp, respectively. In the present study, the REP-PCR technique with a

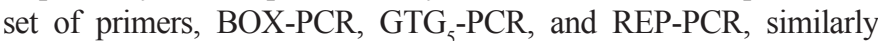
revealed considerable diversity between isolates, generating a similarity dendrogram with four clusters. The fingerprint of isolates assessed presented unique patterns distinguished from the pattern of type strains, with low similarity, indicating that they were derived from distinct strains. About 90\% similarity, indicating similar strains, was observed between 10 of the isolates. Clusters with this similarity were found between the set of primers (BOX-PCR, GTG $-\mathrm{PCR}$, and REP-PCR) and ERIC-PCR. This might be the ERIC primer suitable for the family Enterobacteriaceae than the Bacillus group. Based on these findings, it can be concluded that the use of REPPCR fingerprinting with the primers BOX-PCR, GTG $_{5}-\mathrm{PCR}$, and REP-PCR is beneficial, easy-to-perform, with a single-performance protocol and these approaches have shown to be useful for assessing the genetic diversity of Bacillus strains. Moreover, the consumables and labor cost of these analyses method are significantly lower than those for other genotyping methods (Duan et al., 2009; Olive and Bean, 1999) and also promising genotypic tool for rapid and reliable speciation and grouping of Bacillus species.

Phylogenetic analysis was used to study the relationships of bacteria by comparison of $16 \mathrm{~S}$ rRNA gene sequences with GenBank sequence database using BLAST software. The $16 \mathrm{~S}$ rRNA gene sequence of the isolates exhibited $97.48 \%-98.48 \%$ similarity to the sequences of $B$. coagulans LMG $6326^{\mathrm{T}}$ in NCBI database (Fig. 5). In addition, their phenotypic characteristics

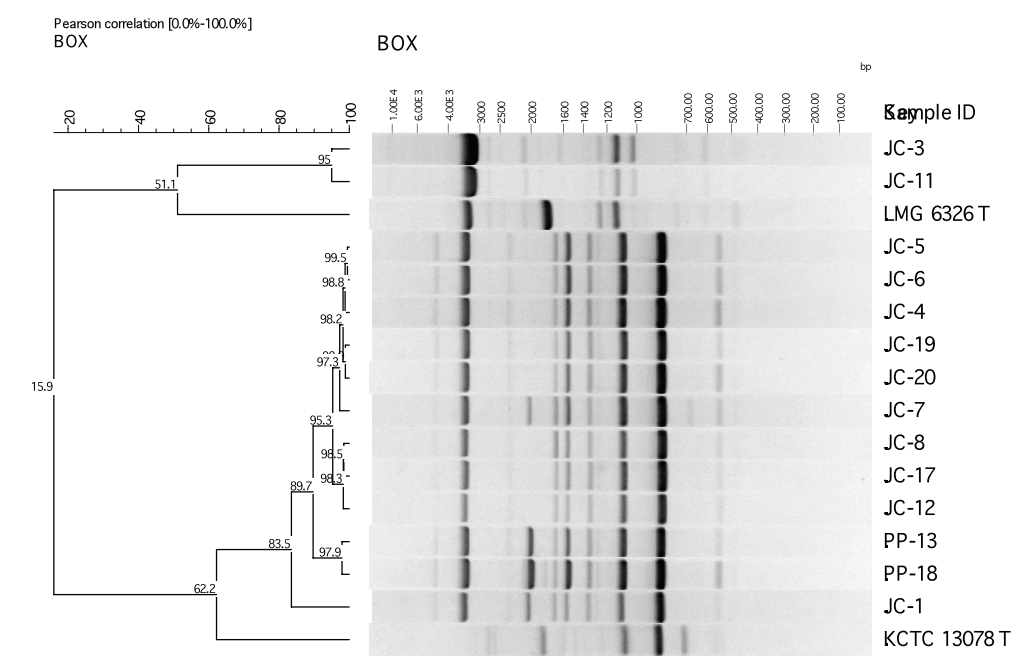

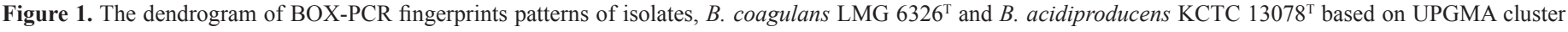
analysis of Pearson correlation coefficient values. 


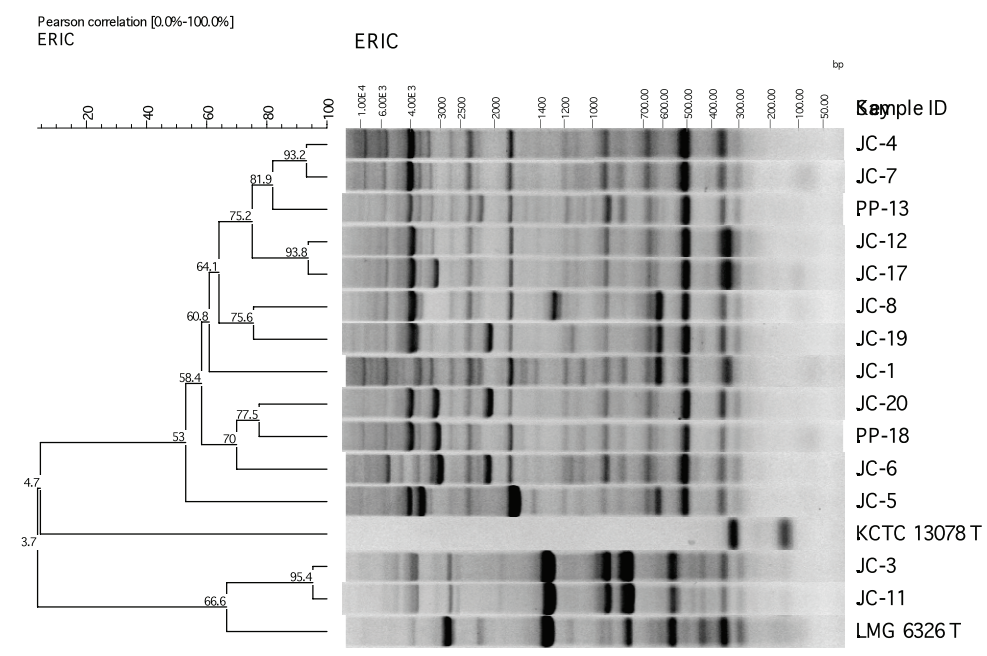

Figure 2. The dendrogram of ERIC-PCR fingerprints patterns of isolates, B. coagulans LMG $6326^{\mathrm{T}}$ and B. acidiproducens $\mathrm{KCTC} 13078^{\mathrm{T}}$ based on UPGMA cluster analysis of Pearson correlation coefficient values.

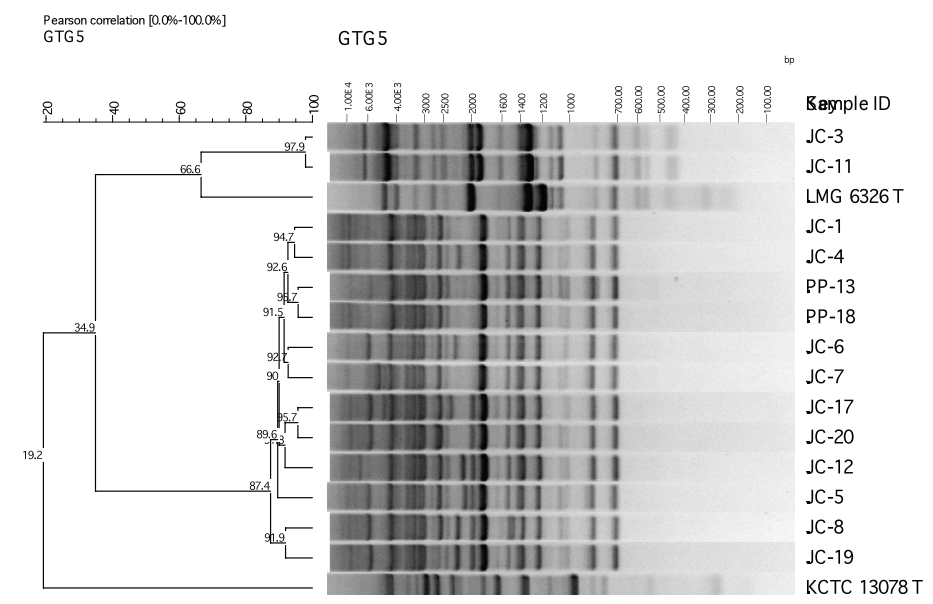

Figure 3. The dendrogram of $\mathrm{GTG}_{5}$-PCR fingerprints patterns of isolates, B. coagulans LMG $6326^{\mathrm{T}}$ and B. acidiproducens $\mathrm{KCTC} 13078^{\mathrm{T}}$ based on UPGMA cluster analysis of Pearson correlation coefficient values.

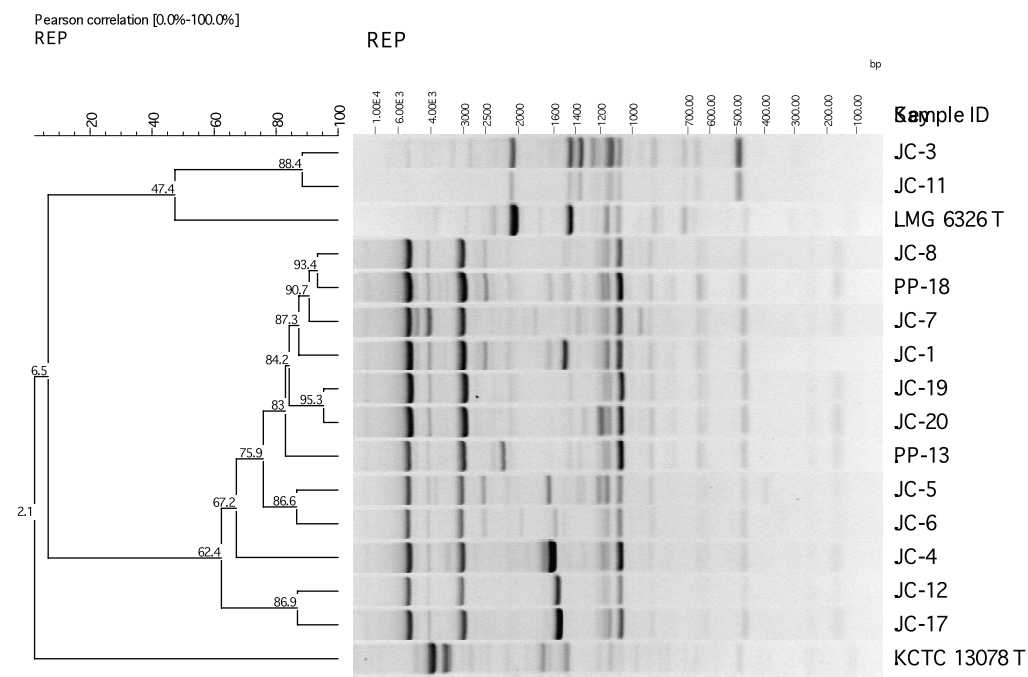

Figure 4. The dendrogram of REP-PCR fingerprints patterns of isolates, B. coagulans LMG $6326^{\mathrm{T}}$ and B. acidiproducens KCTC $13078^{\mathrm{T}}$ based on UPGMA cluster analysis of Pearson correlation coefficient values. 


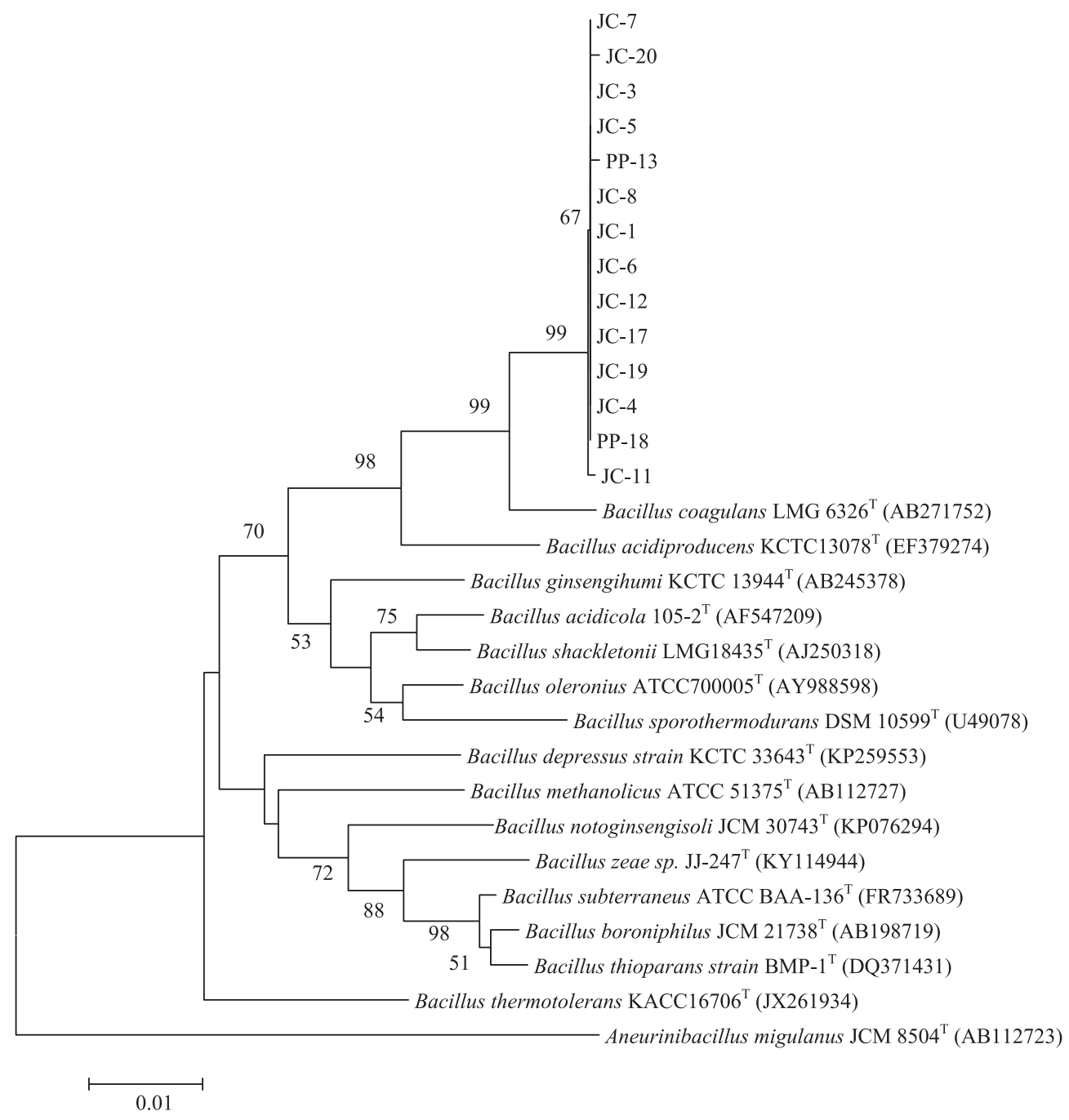

Figure 5. Phylogenetic tree constructed by the neighbour-joining method showing the position of isolates and related Bacillus species based on 16S rRNA gene sequences.

of the isolates showed some differences from $B$. coagulans LMG $6326^{\mathrm{T}}$. However, there were some variable characteristics as in Table 2. Therefore, all the isolates were the novel species of the genus Bacillus based on 16S rRNA gene sequences (De Clerck et al., 2004; Logan et al., 2009) and the further taxonomic characterization is required.

\section{Lactic acid production}

All isolates were catalase positive so they were tested for lactic acid production under aerobic condition. The results on the total lactic acid production, yield, productivity, and qualitative isomer of L-and D-lactic acid by using HPLC of each strain were shown in Table 3. The isolates produce L-lactic acid in the low range $(1.7 \pm 0.1 \mathrm{~g} / \mathrm{l}-32.6 \pm 0.7 \mathrm{~g} / \mathrm{l})$ at $98.58 \% \pm 0.06 \%-100.00 \% \pm 0.00 \%$ optical purity which is far different to the efficiency of the close related type strains, B. coagulans and $B$. acidiproducens. At the same condition, $B$. coagulans LMG $6326^{\mathrm{T}}$ and $B$. acidiproducens KCTC $13078^{\mathrm{T}}$ could produce L-lactic acid at $66.7 \pm 2.8 \mathrm{~g} / 1$ and 82.8 $\pm 1.0 \mathrm{~g} / \mathrm{l}$, respectively. Strain JC-7 showed the highest L-lactic acid production efficiency at $32.6 \pm 0.4 \mathrm{~g} / \mathrm{l}$ with $100.00 \pm 0.00$ optical purity. However, these new species could produce L-lactic acid less than the Bacillus strains as previously reported (Ma et al., 2014; Ohara et al., 1996; Thitiprasert et al., 2017).

\section{Antimicrobial activity}

The result revealed that only Bacillus sp. JC-19 was potentially effective in suppressing the bacterial growth of $K$. rhizophila ATCC 9341. It was also reported antibacterial activities against pathogenic bacteria by $B$. coagulans $\mathrm{CGMCC}$ 9551 isolated from healthy piglet feces (Gu et al., 2015).

\section{CONCLUSION}

In this study, 14 isolates from soil in Thailand were identified as novel Bacillus species based on their physiological and biochemical properties as well as its 16S rRNA genes. With the primers (BOX-PCR, GTG 5 -PCR, and REP-PCR), they showed similar four clusters on dendrogram that belonging to the same species. It showed that some strains, JC-3 and JC- 
Table 3. Lactic acid and residual glucose of isolates.

\begin{tabular}{|c|c|c|c|c|c|c|}
\hline \multirow[b]{2}{*}{ Isolate no. } & \multicolumn{3}{|c|}{ Lactic acid } & \multirow{2}{*}{$\begin{array}{c}\text { Initial } \\
\text { glucose (g/l) }\end{array}$} & \multirow{2}{*}{$\begin{array}{c}\text { Residual } \\
\text { glucose }(\mathrm{g} / \mathrm{l})\end{array}$} & \multirow{2}{*}{$\begin{array}{l}\text { Optical purity o } \\
\text { lactic acid (\%ee) }\end{array}$} \\
\hline & $\begin{array}{c}\text { Final lactic } \\
\text { acid }(\mathrm{g} / \mathrm{l})\end{array}$ & Yield (g/g) & $\begin{array}{c}\text { Productivity } \\
\text { (g//.h) }\end{array}$ & & & \\
\hline PP-13 & $1.7 \pm 0.1$ & $0.67 \pm 0.04$ & $0.02 \pm 0.00$ & 120.00 & $117.45 \pm 0.07$ & $100.00 \pm 0.00$ \\
\hline PP-18 & $12.2 \pm 2.2$ & $0.30 \pm 0.07$ & $0.17 \pm 0.03$ & 120.00 & $79.75 \pm 2.47$ & $100.00 \pm 0.00$ \\
\hline JC-1 & $27.9 \pm 2.6$ & $0.50 \pm 0.02$ & $0.38 \pm 0.04$ & 120.00 & $65.17 \pm 0.92$ & $100.00 \pm 0.00$ \\
\hline JC-3 & $1.8 \pm 0.0$ & $0.74 \pm 0.06$ & $0.03 \pm 0.00$ & 120.00 & $117.55 \pm 0.21$ & $100.00 \pm 0.00$ \\
\hline JC-4 & $12.2 \pm 1.6$ & $0.48 \pm 0.02$ & $0.17 \pm 0.02$ & 120.00 & $94.65 \pm 4.6$ & $100.00 \pm 0.00$ \\
\hline JC-5 & $17.0 \pm 0.2$ & $0.56 \pm 0.01$ & $0.24 \pm 0.00$ & 120.00 & $89.60 \pm 0.85$ & $100.00 \pm 0.00$ \\
\hline JC-6 & $2.5 \pm 0.1$ & $0.60 \pm 0.12$ & $0.03 \pm 0.00$ & 120.00 & $115.85 \pm 0.92$ & $100.00 \pm 0.00$ \\
\hline JC-7 & $32.6 \pm 0.4$ & $0.53 \pm 0.02$ & $0.45 \pm 0.01$ & 120.00 & $58.65 \pm 1.2$ & $100.00 \pm 0.00$ \\
\hline JC-8 & $11.6 \pm 0.0$ & $0.40 \pm 0.01$ & $0.16 \pm 0.00$ & 120.00 & $91.1 \pm 0.42$ & $98.58 \pm 0.06$ \\
\hline JC-11 & $28.2 \pm 0.8$ & $0.56 \pm 0.04$ & $039 \pm 0.01$ & 120.00 & $69.8 \pm 1.98$ & $100.00 \pm 0.00$ \\
\hline $\mathrm{JC}-12$ & $2.4 \pm 0.3$ & $0.28 \pm 0.05$ & $0.03 \pm 0.00$ & 120.00 & $111.1 \pm 2.69$ & $100.00 \pm 0.00$ \\
\hline JC-17 & $25.0 \pm 1.1$ & $0.62 \pm 0.01$ & $0.35 \pm 0.02$ & 120.00 & $79.45 \pm 1.06$ & $100.00 \pm 0.00$ \\
\hline JC-19 & $28.3 \pm 3.6$ & $0.63 \pm 0.05$ & $0.39 \pm 0.00$ & 120.00 & $74.87 \pm 0.57$ & $100.00 \pm 0.00$ \\
\hline JC-20 & $31.8 \pm 2.3$ & $0.82 \pm 0.04$ & $0.44 \pm 0.03$ & 120.00 & $81.25 \pm 4.6$ & $100.00 \pm 0.00$ \\
\hline LMG $6326^{\mathrm{T}}$ & $66.7 \pm 2.8$ & $0.70 \pm 0.02$ & $0.93 \pm 0.04$ & 120.00 & $24.45 \pm 1.2$ & $100.00 \pm 0.00$ \\
\hline KCTC $13078^{\mathrm{T}}$ & $82.8 \pm 1.0$ & $0.69 \pm 0.01$ & $1.15 \pm 0.01$ & 120.00 & $0.00 \pm 0.00$ & $99.68 \pm 0.24$ \\
\hline
\end{tabular}

11, showed highly similar patterns using ERIC primer. The results indicated the potential of REP-PCR technique as a tool for examining relationships among our Bacillus species. For lactic acid production efficiency, the isolate JC-7 showed the highest L-lactic acid production efficiency at $32.6 \pm 0.4 \mathrm{~g} / 1$ with $100.00 \pm 0.00$ optical purity. In addition, only one isolate, JC-19 showed the antimicrobial activity against $K$. rhizophila ATCC 9341.

\section{FINANCIAL SUPPORT AND SPONSORSHIP}

This study was supported by the Grant for International Research Integration: Research Pyramid, Ratchadaphiseksomphot Endowment Fund (GCURP_58_01_33_01), Chulalongkorn University.

\section{CONFLICT OF INTERESTS}

There are no conflicts of interest.

\section{REFERENCES}

Acar JF, Goldstein FW. Disk susceptibility test. In: Lorian V (ed.). Antibiotics in Laboratory Medicine. 3rd edition, Williams and Wilkins, Baltimore, MD, pp 17-52, 1991.

Cowan ST, Steel KJ. 2004. Cowan and Steel's manual for the identification of medical bacteria. London, England: Cambridge University Press.

Da Silva RB, Valicente FH. Molecular characterization of Bacillus thuringiensis using REP-PCR. Springer Plus, 2013; 2(1):641.

De Clerck E, Rodriguez-Diaz M, Forsyth G, Lebbe L, Logan NA, DeVos P. Polyphasic characterization of Bacillus coagulans strains, illustrating heterogeneity within this species, and emended description of the species. Syst Appl Microbiol, 2004; 27(1):50-60.

Duan H, Chai T, Liu J, Zhang X, Qi C, Gao J, Wang Y, Cai Y, Miao Z, Yao M, Schlenker G. Source identification of airborne Escherichia coli of swine house surroundings using ERIC-PCR and REP-PCR. Environ Res, 2009;109(5):511-517.

Ezema C. Probiotics in animal production: a review. J Vet Med Anim Health, 2013; 5(11):308-16.
Felsenstein J. Confidence limits on phylogenies: an approach using the bootstrap. Evolution, 1985; 39(4):783-791.

Feto NA. Bacillus spp. and their biotechnological roles in green industry. In: Bacilli and agrobiotechnology. Springer, Cham, pp 143-162, 2016.

Gevers D, Huys G, Swings J. Applicability of rep-PCR fingerprinting for identification of Lactobacillus species. FEMS Microbiol Lett, 2001; 205(1):31-36.

Gu SB, Zhao LN, Wu Y, Li SC, Sun JR. Potential probiotic attributes of a new strain of Bacillus coagulans CGMCC 9951 isolated from healthy piglet feces. World J Microbiol Biotechnol, 2015; 31:851-863.

Jensen MA, Webster JA, Straus N. Rapid identification of bacteria on the basis of polymerase chain reaction-amplified ribosomal DNA spacer polymorphisms. Appl Environ Microbiol, 1993; 59:945-952.

Kim OS, Cho YJ, Lee K, Yoon $\mathrm{SH}$, Kim $\mathrm{M}, \mathrm{Na} \mathrm{H}$, et al. Introducing EzTaxon-e: a prokaryotic 16S rRNA gene sequence database with phylotypes that represent uncultured species. Int J Syst Evol Microbiol, 2012; 62(3):716-721.

Liao SF, Nyachoti M. Using probiotics to improve swine gut health and nutrient utilization. Ani Nutr, 2017; 3940:331-343.

Logan NA, De Vos P. Genus I. Bacillus. In: De Vos P, Garrity GM, Jones D, Krieg NR, Ludwig W, Rainey FA, et al. (eds.). Bergey's manual of systematic bacteriology. 2nd edition, Springer, New York, NY, pp 21-128, 2009.

Ma K, Maeda T, You H, Shirai Y. Open fermentative production of 1-lactic acid with high optical purity by thermophilic Bacillus coagulans using excess sludge as nutrient. Bioresour Technol, 2014; 151:28-35.

Ohara H, Yahata M. L-lactic acid production by Bacillus sp. in anaerobic and aerobic culture. J Ferment Bioeng, 1996; 8193:272-4.

Olive DM, Bean P. Principles and applications of methods for DNA based typing of microbial organisms. J Clin Microbiol, 1999; 37:1661-1669.

Oliwa-Stasiak K, Kolaj-Robin O, Adley CC. Development of real-time PCR assays for detection and quantification of Bacillus cereus group species: differentiation of $B$. weihenstephanensis and rhizoid $B$. pseudomycoides isolates from milk. Appl Environ Microbiol, 2011; 77(1):80-88.

Prasirtsak B, Tanasupawat S, Boonsombat R, Kodama K, Thongchul $\mathrm{N}$. Characterization of lactic acid producing bacteria from Thai sources. J Appl Pharm Sci, 2013; 3(1):33-38. 
Rampadarath S, Puchooa D, Bal S. Repetitive element palindromic PCR (Rep-PCR) as a genetic tool to study interspecific diversity in Euphorbiaceae family. Electron J Biotechnol, 2015; 18(6):412-417.

Saitou N, Nei M. The neighbor-joining method: a new method for reconstructing phylogenetic trees. Mol Biol Evol, 1987; 4(4):406-425.

Tamura K, Stecher G, Peterson D, Filipski A, Kumar S. MEGA6: molecular evolutionary genetics analysis version 6.0. Mol Biol Evol, 2013; 30(12):2725-2729.

Tanasupawat S, Okada S, Komagata K. Lactic acid bacteria found in fermented fish in Thailand. J Gen Appl Microbiol, 1998; 44(3):193-200.

Thitiprasert S, Kodama K, Tanasupawat S, Prasitchoke P, Rampai T, Prasirtsak B, et al. A homofermentative Bacillus sp. BC-001 and its performance as a potential 1-lactate industrial strain. Bioprocess Biosyst Eng, 2017; 40(12):1787-1799.
Versalovic J, Schneider M, De Bruijn FJ, Lupski JR. Genomic fingerprinting of bacteria using repetitive sequence-based polymerase chain reaction. Methods Mol Cell Biol, 1994; 5(1):25-40.

Vos P, Garrity G, Jones D, Krieg NR, Ludwig W, Rainey FA, Schleifer KH, Whitman W.(eds).2011. Bergey's Manual of Systematic Bacteriology: Volume 3: The Firmicutes. New York, USA: Springer Science \& Business Media.

\section{How to cite this article:}

Tolieng V, Booncharoen A, Nuhwa R, Thongchul N, Tanasupawat S. Molecular identification, L-lactic acid production, and antibacterial activity of Bacillus strains isolated from soils. J App Pharm Sci, 2018; 8(10): 098-105. 